\title{
Revised and Extended Social Commerce Technology Adoption in e-business of Pakistan
}

\author{
Yasir Ali Solangi', Zulfiqar Ali Solangi², Zulfikar Ahmed Maher², Madihah bt. S. Abd. Aziz², Mohd Syarqawy bin \\ Hamzah², Asadullah Shah $^{2}$ \\ Dept Computer Science, Shah Abdul Latif University Khairpur, Pakistan \\ yasir_solangi@yahoo.com \\ Dept Information and Communication Technology, International Islamic University Malaysia, Kuala Lumpur, Malaysia \\ zulfs@hotmail.com \\ Dept Information and Communication Technology, International Islamic University Malaysia, Kuala Lumpur, Malaysia \\ zamaher@gmail.com \\ Dept Information and Communication Technology, International Islamic University Malaysia, Kuala Lumpur, Malaysia \\ madihahs@iium.edu.my \\ Dept Information and Communication Technology, International Islamic University Malaysia, Kuala Lumpur, Malaysia \\ syarqawy@iium.edu.my \\ Dept Information and Communication Technology, International Islamic University Malaysia, Kuala Lumpur, Malaysia \\ asadullah@iium.edu.my
}

\begin{abstract}
Social commerce is a new perspective change in modern electronic business procedures bringing together individuals on social media sites and opens up another electronic social marketing channel to establish business. In developing countries like Pakistan, e-business can help organizations using social commerce and social marketing intelligently on particular social network sites to grasp their business clients while they are interacting with their online community on the social media sites. This study investigated consumers' behavior towards adoption of social commerce and introduced a revised and extended social commerce technology model. The investigation proved the proposed model is valid by confirming loading factor, Kaiser-Mayer-Olkin (KMO), reliability analysis, and structural equation modeling approach for hypotheses tests. The study found Perceived Ease of Use (PEU), Perceived Usefulness (PU), Social Media Influence (SMI), and Risk (RI) have significant impact on social commerce adoption in e-business of Pakistan. More, Trust (TR) and Web experience (WXP) were insignificant that revealed the preventive behavior towards adoption of social commerce in e-business of Pakistan.
\end{abstract}

Keywords-Social commerce, e-business, Social Media, Social trade, e-commerce, Social consumers, Web2.0

\section{INTRODUCTION}

Fast sharing and social media intelligence of individuals has given new open doors cum difficulties to organizations to get a handle on their new clients by means of conjuncture of internet based social life advancements and online business. In developing countries like Pakistan, e-business can help organizations using social marketing intelligently on particular social network sites to grasp their business clients while they are interacting with their online community on one of the social media sites. As indicated by Pakistan futuristic customer study completed by Google, a normal 150 minutes are spent in online exercises via web-based networking media. Internet based social life stage has turned out to be a wellspring of legitimate data about organizations and their items among clients via posting and sharing either positive or negative review points about a particular business product [1]. Social trade is a sort of electronic trade, which utilizes structures to help the gaining of the offering of business items. This sort of trade uses client appraisals, referrals, online get-togethers and social lifting to invigorate electronic shopping. These days, the progression of web business in the modernized economy has instigated social trade (s-commerce) as another point of view. S-commerce, for the most part, intimates online trade applications that handle electronic casual posts using Web 2.0 technology[2]. Web 2.0 has given another approach with different sort of online platform where the customers can without much of stretch share sentiments; convictions and observations comprehensively open by means of Internet based social life. Sharing data on line is presently conceivable because of Web 2.0[3]. Social media is a broadly open and informal platform of sharing and communication hence, users are vigorously linking to both social media 
platforms for online purchases, as shown in Figure 1 a high increase in retail e-commerce sale worldwide by statistica (2018).

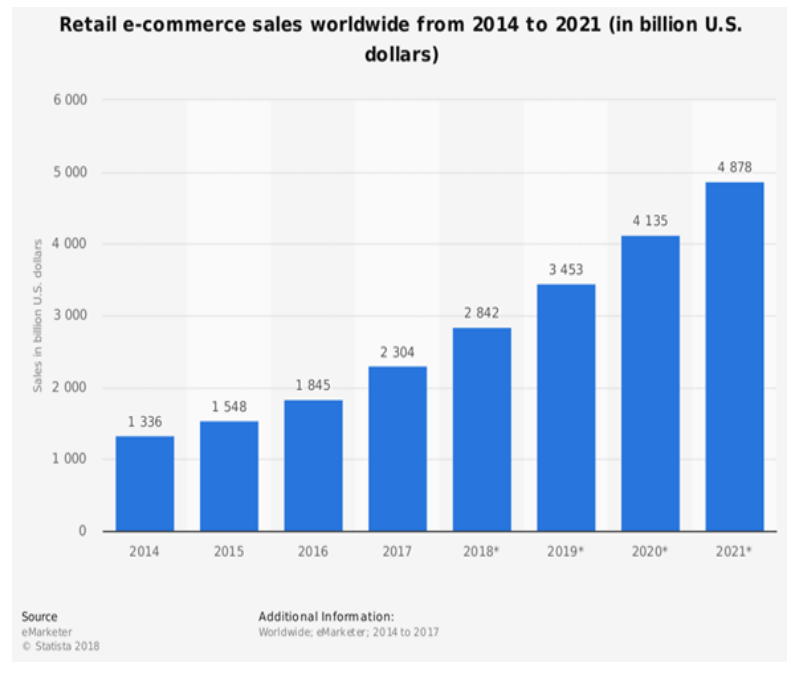

Fig 1 source: Statistica 2018

As organizations around the globe have exploited the intensity of Internet and social networking sites and began to explore and receive the best techniques to fuse it into their plans of action in their businesses and marketing[4] [5][6]. In Pakistan, small businesses have started using social media platforms to incorporate their businesses with social media and e-business activities. Sharing posts about product reviews and ratings makes social media powerful tool and vital for customers during purchase decision online[7]. Social commerce is a subset of electronic commerce trade that combines electronic individual toindividual casual communication, online media that supports social cooperation, and client obligations with respect to encourage the online purchasing and promotion of business products by e-business organizations. Even more, social commerce is the utilization of social harmony effort in favor or disfavor the e-business. S commerce is a new perspective change in procedures bringing together individuals on social media sites and opens up another online social marketing field to examine.

Further, the paper is organized as follows. Section 2 provides the background information, followed by Proposed Research Framework in Section 3, Research Methodology in Section 4, Results in Section 5. Then after Hypotheses Testing and Discussion in Section 6. Finally, Section 7 concludes the study findings.

\section{BACKGROUND}

Pakistan is a developing at 4.87 for every annum and sixth largest population in South Asia region with 190.77 million people [8]. Data Innovation has disturbed the legitimate structures and execution of wide-ranging of society private and other social relationship around the world. Since 1990s, data framework applications have penetrated into all estimations of human life. The fundamental utilization of PC artifacts was "computerization" of the standard shopping and businesses, along these lines, the development played backoffice part in the various leveled business procedures [9]. Social commerce or social business has diverse implications in modern internet business so it has no particular definition [10]. Social commerce is a web-based business involving social networking sites to expedite customers to join in online trade, comparing, and sharing information about business products in an online communities or markets[11][12]. Pakistan is on the course to modernized techniques for organizations and businesses. Pakistan is one of the developing economies, experiencing awesome and dreadful experiences, nevertheless, unless adequate measures are exhibited in re-trying the development to conclude the endeavors most specifically in online business organizations[10]. The country over IT workshops, exhibitions and competitions are being engineered and public areas are equipped with advanced internet hotspots to ensure IT and web use. Several departments and entrepreneurs have been involved to set up and manage the distinctive localities of the technological advancement and its procedures with help to gather opportunities of the digital age [10]. According to an investigation of the 54 SMEs[11], $84 \%$ of the business firms had web accounts, $46 \%$ have ensured ordinary to above gathering of e-business. Additionally, $59 \%$ of the affiliations had either an in-house or vendor maintained web servers and $67 \%$ business firms owned the home pages [12] . Consenting to Ibrahim report [1] e-business is creating at yearly rate of half per annum that in Pakistan, where computerization and automation of business organization is growing at the rate of $30 \%$ consistently; in like manner, Pakistan imported 350,000 Internet and automation structures in 2002-2003, where the request of portable technology raised to $35 \%$ which was $15 \%$ previously. In the same year, Pakistan transported in IT hardware and related devices worth \$20 million.

According to reports published in January 2018 [13], social media has gained more popularity in Pakistan and it has key social media marketing information for anyone doing business in Pakistan. Social media has produced social marketplace by integrating social networks into online local business firms, letting the customers look for purchases from their social media friends or friends of friends online [14]. Due to growing use of social marketplace by the private and public sector business in Pakistan, this paper intends to investigate opportunities, challenges, and solutions for promising s-commerce. 


\section{PROPOSED FRAMEWORK AND RESEARCHS HYPOTHESES}

Figure 2. Represents hypothetical research framework with six casual paths of endogenous and exogenous factors of social commerce adoption. While Table 1 and Table 2 details the constructs and hypotheses description respectively.

TABLE I KEY CONSTRUCT OF THE MODLE

\begin{tabular}{|c|c|c|}
\hline Theory & Construct & Description \\
\hline TAM & $\begin{array}{l}\text { Perceived } \\
\text { Ease of } \\
\text { Use (PEU) }\end{array}$ & $\begin{array}{l}\text { Concerning this study, it } \\
\text { alludes to the degree to } \\
\text { which a customer trusts } \\
\text { that buying goods and } \\
\text { services using the social } \\
\text { web will be free of } \\
\text { exertion [15] }\end{array}$ \\
\hline TAM & $\begin{array}{l}\text { Perceived } \\
\text { Usefulness } \\
\text { (PU) }\end{array}$ & $\begin{array}{l}\text { Concerning this study, it } \\
\text { alludes to the degree to } \\
\text { which a customer trusts } \\
\text { that buying goods and } \\
\text { services using the social } \\
\text { web will be free of } \\
\text { exertion [15] }\end{array}$ \\
\hline TRA & $\begin{array}{c}\text { Social } \\
\text { Media } \\
\text { Influence } \\
\text { (SMI) } \\
\text { (Subjective } \\
\text { Norm) } \\
\end{array}$ & $\begin{array}{l}\text { "A subjective norm is } \\
\text { the perceived social } \\
\text { pressure to engage or } \\
\text { not to engage in a } \\
\text { behavior." [16]. }\end{array}$ \\
\hline \multirow[t]{3}{*}{$\begin{array}{l}\text { External } \\
\text { Factors }\end{array}$} & Trust (TR) & $\begin{array}{l}\text { "Trust is a crucial } \\
\text { enabling factor in online } \\
\text { transactions, where } \\
\text { there is uncertainty, } \\
\text { information asymmetry } \\
\text { and fear of } \\
\text { opportunism". Absence } \\
\text { of trust is the key reason } \\
\text { that keeps buyers } \\
\text { change their gesture to } \\
\text { buy online [17]. }\end{array}$ \\
\hline & Risk (RI) & $\begin{array}{l}\text { The risk is "the } \\
\text { purchaser's insight of } \\
\text { unpredictability or the } \\
\text { unreliability regarding } \\
\text { unfavorable outcomes } \\
\text { of the products and } \\
\text { services" [18]. }\end{array}$ \\
\hline & $\begin{array}{c}\text { Web } \\
\text { Experience } \\
(\mathrm{WXP})\end{array}$ & $\begin{array}{l}\text { "e-consumers rely } \\
\text { heavily on awareness } \\
\text { abilities, which can only } \\
\text { be developed over vast }\end{array}$ \\
\hline
\end{tabular}

\begin{tabular}{|l|l|l|}
\hline Theory & Construct & \multicolumn{1}{c|}{ Description } \\
\hline & & $\begin{array}{l}\text { experience with e- } \\
\text { purchasing [19]. }\end{array}$ \\
\hline
\end{tabular}

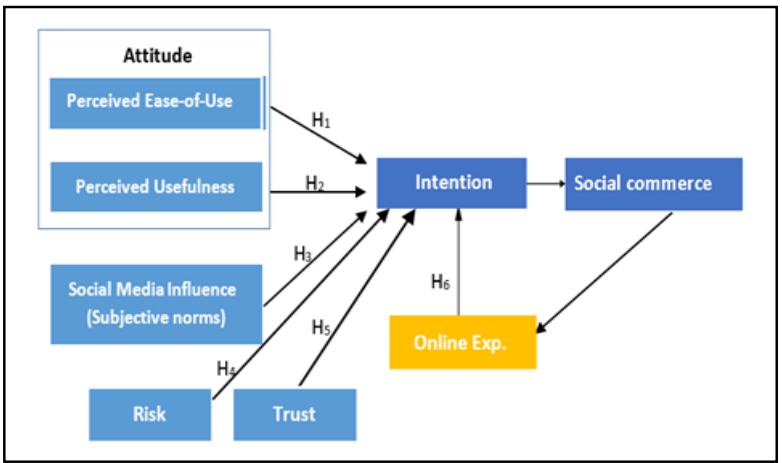

Fig 2 Proposed Research Frame work

TABLE II CONSTRUCTS HYPOTHETICAL RELATIONSHIP

\begin{tabular}{|c|c|c|}
\hline $\begin{array}{l}\mathrm{R} \\
\mathrm{H}\end{array}$ & $\begin{array}{l}\text { Research } \\
\text { Hypotheses }\end{array}$ & $\begin{array}{l}\text { Hypothetical Relationship } \\
\text { of Constructs }\end{array}$ \\
\hline 1 & $\begin{array}{l}\text { H1: Attitude } \\
\text { towards } \\
\text { perceived ease of } \\
\text { use of e-business } \\
\text { will have positive } \\
\text { influence on } \\
\text { intention to use s- } \\
\text { commerce }\end{array}$ & $\begin{array}{l}\text { Attitude } \rightarrow \text { PEU } \rightarrow \text { Social } \\
\text { Commerce adoption }\end{array}$ \\
\hline 2 & $\begin{array}{l}\text { H2: Attitude } \\
\text { towards } \\
\text { usefulness of e- } \\
\text { business } \\
\text { have will } \\
\text { influence positive } \\
\text { intention to use s- } \\
\text { commerce. }\end{array}$ & $\begin{array}{l}\text { Attitude } \rightarrow \text { PU } \rightarrow \text { Social } \\
\text { Commerce adoption }\end{array}$ \\
\hline 3 & $\begin{array}{l}\text { H3: Social media } \\
\text { influence will } \\
\text { have positive } \\
\text { impact on } \\
\text { intention to adopt } \\
\text { S-commerce }\end{array}$ & $\begin{array}{l}\text { SMI } \rightarrow \text { Social Commerce } \\
\text { adoption }\end{array}$ \\
\hline 4 & $\begin{array}{l}\mathrm{H}_{4}: \text { Risk will } \\
\text { negatively affect } \\
\text { the behavioral } \\
\text { intention to use } \\
\text { social commerce. }\end{array}$ & $\begin{array}{l}\mathrm{RI} \rightarrow \text { Social Commerce } \\
\text { adoption }\end{array}$ \\
\hline 5 & $\begin{array}{l}\text { H5: Trust will } \\
\text { have positive }\end{array}$ & $\begin{array}{l}\mathrm{TR} \rightarrow \text { Social Commerce } \\
\text { adoption }\end{array}$ \\
\hline
\end{tabular}




\begin{tabular}{|l|l|l|}
\hline $\begin{array}{l}\text { R } \\
\text { H } \\
\#\end{array}$ & Research & Hypotheses \\
& $\begin{array}{l}\text { influence } \\
\text { intention to use } \\
\text { of Constructs commerce. }\end{array}$ & \\
\hline 6 & $\begin{array}{l}\text { H}_{6}: \text { Web } \\
\text { experience will } \\
\text { positively } \\
\text { influence } \\
\text { intention to use } \\
\text { social commerce. }\end{array}$ & $\begin{array}{l}\text { WXP } \rightarrow \text { Social Commerce } \\
\text { adoption }\end{array}$ \\
\hline
\end{tabular}

\section{RESEARCH METHODOLOGY}

In order to reach the research objectives and research hypotheses, the quantitative research methodology was utilized and adopted the structured questionnaire survey for data collection. Investigative acceptance and use of social commerce and its significance of adoption in e-business of Pakistan completed this part of a study. This research study was approved to conduct the survey from all individuals both business consumers and retailers with or without a social media account potentially constituted the population of interest. The researcher considered more specifically business consumers residing in metropolitan cities of Pakistan. Four senior researchers to find out ambiguities reviewed the earliest survey questionnaire draft and unclear items of the survey, consequently, required changes improved the survey readability. At last, the questionnaire was prepared to be spread in six metropolitan urban communities of Pakistan. Furthermore, a portion of the surveys was gathered from regional urban areas to give a superior comprehension of the present circumstance.

\section{A. Data Collection and Instrument}

The researcher utilized both online electronic surveyor form of Google, for the individuals who were not accessible online since, paper-based survey was set up for those respondents. The survey was organized with structured and unstructured items, which were short and brief with the multiple choice options (Strongly disagree to strongly agree). The survey contained of three areas with the main effort to build up the statistic demographics of the respondents, the second part, to know background information about internet, social media, and social commerce among the potential respondents. The third part was to measure the latent and external factors towards adoption of social commerce in e-business of Pakistan.

\section{B. Data Analysis}

Several statistical techniques and procedures were applied like frequencies, percentages, and measures of central tendency, mean commutative percentages, mean, standard deviation, reliability using Cronbach's Alpha, factor loading, and t-test to investigate the significant factors of social commerce in e-business of Pakistan by testing and test and validating proposed research hypotheses in the precision of TAM and TRA theories.

\section{RESULTS}

A. Questionnaire reliability using Cranach's Alpha

The Cronbach's Alpha test results that proved the questionnaire survey reliability and validity. All the factors were exceeding the Cronbach's a acceptable score ( 0.72 to 0.99) verified the reliability of collected data [20]. Table 3 shows all the values of Cronbach's alpha for all factors. The value ranges from 0.71 to 0.96 . Perceived ease of use and perceived usefulness had values 0.82 and 0.78 respectively. Social media influence was (0.89), risk (0.71), trust (0.70), web experience (0.72), and s-commerce use (0.96) with the highest value that shows the more reliability towards use of social commerce in e-business.

TABLE III RELIABILITY STATISTICS OF FACTORS

\begin{tabular}{|c|l|c|}
\hline S\# & \multicolumn{1}{|c|}{ Construct } & Cronbach's $\alpha$ \\
\hline 1 & $\begin{array}{l}\text { Perceived ease of use } \\
\text { (PEU) }\end{array}$ & 0.82 \\
\hline 2 & $\begin{array}{l}\text { Perceived Usefulness } \\
(\text { PU) }\end{array}$ & 0.78 \\
\hline 3 & $\begin{array}{l}\text { Social Media Influence } \\
\text { (SMI) }\end{array}$ & 0.71 \\
\hline 4 & Risk(RI) & 0.70 \\
\hline 5 & Trust(TR) & 0.72 \\
\hline 6 & Web Expereince (Wxp) & 0.96 \\
\hline 7 & $\begin{array}{l}\text { S-Commerce use } \\
\text { (SCU) }\end{array}$ \\
\hline
\end{tabular}

\section{A. Exploratory Factor Analysis}

Exploratory Factor Analysis (EFA) was performed for investigation of large-scale data collection among observed variables and to ensure proposed research framework validity. Principal components analysis (PCA) and Orthogonal method with Varimax rotation was performed via SPSS24.0. The Varimax analysis technique measures three values. First, the loading of factors which must be more 0.4 [21]. Second, KMO value, which ensure the sample size and fitness, is enough to perform factor analysis. KMO test result was $(0.81)$ of the factor model that is more than the acceptable value (more than 0.5 ) as suggested to be closer to (1.0) by [22] and Barlett test of sphericity indicated that the data were appropriate for factors study in Table 4 . The significant test value is recommended $(\mathrm{p}<0.05)$ according to[22] and Bartletts' test of factor model was less than 0.01.Finally, in Table 6 eigen value that is recommended to be more than 1.0 according to Kaiser's criterion and [21]. Table 5 show the factor analysis results that confirms the validity of proposed research framework. 
TABLE IV 4 KMO Statistics and Bartlett's Test of Sphericity

\begin{tabular}{|c|c|c|}
\hline \multicolumn{2}{|c|}{$\begin{array}{c}\text { Kaiser-Meyer-Olkin Measure of } \\
\text { Sampling Adequacy }\end{array}$} & 0.81 \\
\hline \multirow{3}{*}{$\begin{array}{c}\text { Bartlett's Test of } \\
\text { Sphericity }\end{array}$} & $\begin{array}{c}\text { Approx. Chi- } \\
\text { Square }\end{array}$ & 7795.805 \\
\cline { 2 - 3 } & DF & 820 \\
\cline { 2 - 3 } & Sig. & .000 \\
\hline
\end{tabular}

TABLE V LOADING FACTORS

\begin{tabular}{|c|c|c|c|c|c|c|c|c|c|}
\hline \multicolumn{10}{|c|}{ Rotated Component Matrix ${ }^{a}$} \\
\hline & \multicolumn{9}{|c|}{ Component } \\
\hline & 1 & 2 & 3 & 4 & 5 & 6 & 7 & 8 & 9 \\
\hline $\mathrm{SCU}_{1}$ & .748 & & & & & & & & \\
\hline $\mathrm{SCU}_{2}$ & .736 & & & & & & & & \\
\hline $\mathrm{SCU}_{3}$ & .802 & & & & & & & & \\
\hline $\mathrm{SCU}_{4}$ & .815 & & & & & & & & \\
\hline $\mathrm{SCU}_{5}$ & .845 & & & & & & & & \\
\hline SCU6 & .828 & & & & & & & & \\
\hline PEU1 & & .870 & & & & & & & \\
\hline PEU2 & & .891 & & & & & & & \\
\hline PEU3 & & .875 & & & & & & & \\
\hline PEU4 & & .788 & & & & & & & \\
\hline PEU5 & & .856 & & & & & & & \\
\hline PU1 & & & .773 & & & & & & \\
\hline PU2 & & & .775 & & & & & & \\
\hline $\mathrm{PU}_{3}$ & & & .811 & & & & & & \\
\hline PU4 & & & .739 & & & & & & \\
\hline SMl1 & & & & .721 & & & & & \\
\hline $\mathrm{SMI} 2$ & & & & .792 & & & & & \\
\hline $\mathrm{SMI}_{3}$ & & & & .809 & & & & & \\
\hline $\mathrm{SMI} 4$ & & & & .829 & & & & & \\
\hline RI1 & & & & & .815 & & & & \\
\hline $\mathrm{R} / 2$ & & & & & .854 & & & & \\
\hline $\mathrm{R} 13$ & & & & & .837 & & & & \\
\hline $\mathrm{R} / 4$ & & & & & .805 & & & & \\
\hline TR1 & & & & & & .821 & & & \\
\hline
\end{tabular}

\begin{tabular}{|l|l|l|l|l|l|l|l|l|l|}
\hline \multicolumn{7}{|c|}{ Rotated Component Matrix ${ }^{\mathrm{a}}$} \\
\hline TR2 & & & & & & .852 & & & \\
\hline TR3 & & & & & .844 & & & \\
\hline TR4 & & & & & .799 & & & \\
\hline Wxp1 & & & & & & .702 & & \\
\hline Wxp2 & & & & & & .774 & \\
\hline Wxp3 & & & & & & .785 & \\
\hline Wxp4 & & & & & & .824 & \\
\hline Wxp5 & & & & & & .812 & \\
\hline $\begin{array}{l}\text { Extraction Method: Principal Component Analysis. } \\
\text { Rotation Method: Varimax with Kaiser }\end{array}$ \\
Normalization. ${ }^{\text {a }}$ \\
a. Rotation converged in 6 iterations. \\
\hline
\end{tabular}

\section{HYPOTHESES TESTING AND DISCUSSION}

This section discusses the underlying hypotheses presented in Table 2. Six casual paths $\left(\mathrm{H}_{1}, \mathrm{H}_{2}, \mathrm{H}_{3}, \mathrm{H}_{4}, \mathrm{H}_{5}\right.$, and $\mathrm{H}_{6}$ verified the relationship between latent factors of the hypothetical research framework. Statistical analysis of seven factors is shown in table 7. Perceived Ease of Use (PEU), Perceived Usefulness (PU), Social Media Influence (SMI), Risk (RI), Trust (TR), Web Experience (WXP), and S Commerce Usage (SCU). The structural model parameter measurements were utilized to assess covariance matrix for the structural model, which is the most vital piece of the structural model figuring coefficient parameter estimations. Total number of 31 observed variables related to seven latent factors were observed in the final model. The covariance matrix among the constructs was applied to test the model. "When the critical ratio ( $C R$ or $t$-value) was higher than \pm 1.96 for an estimate (regression weight), then the parameter coefficient value was statistically significant at the p-value less than .05 levels" (Hair et al., 2010). The researcher divided regression weight estimate by standard error (S.E) to calculate the critical ratio (CR) or t-value. Finally, the $C R$ values and path estimates of the factors confirmed and verified the causal paths in this research study. For four causal paths estimates, $t$-values were above the \pm 1.96 critical values at the significant level $p$-value $\leq .05$. Hence, the investigation confirmed paths between $(\mathrm{SCU} \rightarrow \mathrm{PEU}),(\mathrm{SCU} \rightarrow \mathrm{PU}),(\mathrm{SCU} \rightarrow \mathrm{SMI})$, and $(\mathrm{SCU} \rightarrow \mathrm{RI})$ were statistically significant. Similarly last two causal relations between $(\mathrm{SCU} \rightarrow \mathrm{TR})$ and $(\mathrm{SCU} \rightarrow \mathrm{WXP})$ were statistically insignificant 
TABLE V NO. OF FACTORS EXTRACTED AND TOTAL VARIANCE EXPLAINED IN EFA MODEL

\begin{tabular}{|c|c|c|c|c|c|c|c|c|c|}
\hline \multicolumn{10}{|c|}{ Total Variance Explained } \\
\hline \multirow[t]{2}{*}{ S\# } & \multicolumn{3}{|c|}{ Initial Eigenvalues } & \multicolumn{3}{|c|}{$\begin{array}{l}\text { Extraction Sums of Squared } \\
\text { Loadings }\end{array}$} & \multicolumn{3}{|c|}{$\begin{array}{c}\text { Rotation Sums of Squared } \\
\text { Loadings }\end{array}$} \\
\hline & Total & $\begin{array}{c}\% \text { of } \\
\text { Variance }\end{array}$ & Cumulative \% & Total & $\begin{array}{c}\% \text { of } \\
\text { Variance }\end{array}$ & Cumulative \% & Total & $\begin{array}{c}\% \text { of } \\
\text { Variance } \\
\end{array}$ & Cumulative \% \\
\hline 1 & 9.157 & 22.334 & 22.334 & 9.157 & 22.334 & 22.334 & 4.693 & 11.448 & 11.448 \\
\hline 2 & 3.954 & 9.645 & 31.978 & 3.954 & 9.645 & 31.978 & 3.753 & 9.153 & 20.600 \\
\hline 3 & 3.415 & 8.330 & 40.308 & 3.415 & 8.330 & 40.308 & 3.731 & 9.100 & 29.700 \\
\hline 4 & 2.776 & 6.771 & 47.079 & 2.776 & 6.771 & 47.079 & 3.189 & 7.777 & 37.477 \\
\hline 5 & 2.520 & 6.147 & 53.226 & 2.520 & 6.147 & 53.226 & 3.087 & 7.530 & 45.007 \\
\hline 6 & 2.399 & 5.851 & 59.078 & 2.399 & 5.851 & 59.078 & 2.949 & 7.192 & 52.199 \\
\hline 7 & 2.272 & 5.542 & 64.619 & & & & & & \\
\hline \multicolumn{10}{|c|}{ *For factors that have eigenvalues less than 1.0 are not shown and truncated } \\
\hline
\end{tabular}

TABLE VII HYPOTHESES TESTING RESULTS WITH REGRESSINO WEIGHTS OF LATENT CONSTRUCTS IN STRUCTURAL MODLE

\begin{tabular}{|c|c|c|c|c|c|c|c|c|c|}
\hline \multicolumn{10}{|c|}{ Total Variance Explained } \\
\hline \multirow[t]{2}{*}{ S\# } & \multicolumn{3}{|c|}{ Initial Eigenvalues } & \multicolumn{3}{|c|}{$\begin{array}{l}\text { Extraction Sums of Squared } \\
\text { Loadings }\end{array}$} & \multicolumn{3}{|c|}{$\begin{array}{c}\text { Rotation Sums of Squared } \\
\text { Loadings }\end{array}$} \\
\hline & Total & $\begin{array}{c}\% \text { of } \\
\text { Variance }\end{array}$ & Cumulative \% & Total & $\begin{array}{c}\% \text { of } \\
\text { Variance }\end{array}$ & Cumulative \% & Total & $\begin{array}{c}\% \text { of } \\
\text { Variance }\end{array}$ & Cumulative \% \\
\hline 1 & 9.157 & 22.334 & 22.334 & 9.157 & 22.334 & 22.334 & 4.693 & 11.448 & 11.448 \\
\hline 2 & 3.954 & 9.645 & 31.978 & 3.954 & 9.645 & 31.978 & 3.753 & 9.153 & 20.600 \\
\hline 3 & 3.415 & 8.330 & 40.308 & 3.415 & 8.330 & 40.308 & 3.731 & 9.100 & 29.700 \\
\hline 4 & 2.776 & 6.771 & 47.079 & 2.776 & 6.771 & 47.079 & 3.189 & 7.777 & 37.477 \\
\hline 5 & 2.520 & 6.147 & 53.226 & 2.520 & 6.147 & 53.226 & 3.087 & 7.530 & 45.007 \\
\hline 6 & 2.399 & 5.851 & 59.078 & 2.399 & 5.851 & 59.078 & 2.949 & 7.192 & 52.199 \\
\hline 7 & 2.272 & $5 \cdot 542$ & 64.619 & & & & & & \\
\hline \multicolumn{10}{|c|}{ For factors that have eigenvalues less than 1.0 are not shown and truncated } \\
\hline
\end{tabular}




\section{CONCLUSION}

All statistical methods and techniques were applied from screening the data to factor analysis, and hypotheses testing. Exploratory factor analysis technique was performed to extract the latent factors. Some of the cross-loaded factor items were removed from the rotated component matrix. Structural equation modeling (SEM) approach was utilized as a main analytical method of testing for six hypotheses and relationships among the constructs of the proposed research framework. However, four out of six hypotheses i.e. $\mathrm{H}_{1}, \mathrm{H}_{2}, \mathrm{H}_{3}$, and $\mathrm{H}_{4}$ were statistically significant and confirmed that Perceived ease of use PEU, Perceived Usefulness (PU), Social Media Influence (SMI), and Risk (RI) were significant factors for successful adoption of social commerce in e-business of Pakistan. Similarly, $\mathrm{H}_{5}$, and $\mathrm{H} 6$ were statistically insignificant that proved Trust (TR) and Web Experience (WXP) external factors were insignificant. Hence, both factors caused future barriers or challenges to adopt social commerce successfully in ebusiness of Pakistan. These factors postures the future challenges for researchers to reconsider the resistance of social commerce adoption in e-business of Pakistan. The reason behind is the Risk factor significance with $t$-value (2.0), which shows high risk behavior of businessmen and consumers associated with the new technology specifically Internet business. This is creating preventive behavior towards adoption of innovation in e-business of Pakistan.

\section{REFERENCES}

[1] Y. Bai, Z. Yao, and Y.-F. Dou, "Effect of social commerce factors on user purchase behavior: An empirical investigation from renren.com," Int. J. Inf. Manage., vol. 35, no. 5, pp. 538-550, 2015.

[2] A. H. Busalim and A. R. C. Hussin, "Understanding social commerce: A systematic literature review and directions for further research," Int. J. Inf. Manage., vol. 36, no. 6, pp. 10751088, 2016.

[3] S. V Scott and W. J. Orlikowski, "Great expectations: The materiality of commensurability in social media," Mater. Organ. Soc. Interact. a Technol. world, vol. 113, 2012.

[4] J. Coelho and C. Duarte, "A literature survey on older adults' use of social network services and social applications," Comput. Human Behav., vol. 58, pp. 187-205, 2016.

[5] E. Enginkaya and H. YIlmaz, "What drives consumers to interact with brands through social media? A motivation scale development study," Procedia-Social Behav. Sci., vol. 148, pp. 219-226, 2014

[6] M. M. Rathore, A. Ahmad, A. Paul, and S. Rho, “Urban planning and building smart cities based on the internet of things using big data analytics," Comput. Networks, vol. 101, pp. 63-80, 2016.

[7] M. R. Solomon, Consumer behaviour: A European perspective. Pearson education, 2010.

[8] F. Division, "Highlights: Pakistan Economic Survey 2014-15," 2014.

[9] K. C. Laudon and C. G. Traver, E-commerce. Pearson, 2013.

[10] W. Nadeem, Examining consumers' acceptance of social commerce in clothing e-retail. 2016.

[11] X. Lin, Y. Li, and X. Wang, "Social commerce research: Definition, research themes and the trends," Int. J. Inf. Manage., 2015.

[12] G. M. Kundi and B. Shah, "IT IN PAKISTAN: THREATS \& OPPORTUNITIES FOR EBUSINESS,” EJISDC, vol. 36, no. 8, pp. 1-31, 2009.

[13] Social Bakers, "Social Media Statistics for the top 20 brands in Pakistan," 2018. [Online]. Available: https://www.socialbakers.com/resources/reports/pakistan/20 18/january/.

[14] M. Jotkar, G. Swaminathan, V. Theofilis, and R. Govindarajan, "On global instability of variable aspect ratio channel flows," in 42nd AIAA Fluid Dynamics Conference and Exhibit, 2012, p. 3273.

[15] C.-M. Chiu, C.-C. Chang, H.-L. Cheng, and Y.-H. Fang, "Determinants of customer repurchase intention in online shopping," Online Inf. Rev., vol. 33, no. 4, pp. 761-784, 2009.

[16] I. Ajzen, "The theory of planned behavior," Organ. Behav. Hum. Decis. Process., vol. 50, no. 2, pp. 179-211, 1991.

[17] D. H. McKnight, V. Choudhury, and C. Kacmar, "The impact of initial consumer trust on intentions to transact with a web site: a trust building model," J. Strateg. Inf. Syst., vol. 11, no. 3-4, pp. 297-323, 2002.

[18] A. Mukhtar and M. Mohsin Butt, "Intention to choose Halal products: the role of religiosity," J. Islam. Mark., vol. 3, no. 2, pp. 108-120, 2012.

[19] C. Dennis Bill Merrilees Chanaka Jayawardhena Len Tiu Wright, C. Dennis, B. Merrilees, C. Jayawardhena, and L. Tiu Wright, "European Journal of Marketing E-consumer behaviour," Eur. J. Mark. Int. J. Serv. Ind. Manag. Int. J. Retail \&amp Distrib. Manag. Iss J. Consum. Mark., 2009.

[20] J. C. Nunnally and I. H. Bernstein, "Psychometric theory," PsycCRITIQUES, vol. 24. pp. 275-280, 1979.

[21] D. T. Holt, M. W. Rutherford, and D. F. Kuratko, "Advancing the field of family business research: Further testing the measurement properties of the F-PEC," Fam. Bus. Rev., vol. 23, no. 1, pp. 76-88, 2010.

[22] V. V. Kamadi, A. R. Allam, and S. M. Thummala, "A computational intelligence technique for the effective diagnosis of diabetic patients using principal component analysis (PCA) and modified fuzzy SLIQ decision tree approach," Appl. Soft Comput., vol. 49, pp. 137-145, 2016. 